BLS 33, No 1 2007. DOI: http://dx.doi.org/10.3765/bls.v33i1.3545

(published by the Berkeley Linguistics Society and the Linguistic Society of America)

\title{
Political Ideology and Language Policy in North Korea
}

\author{
JACOB A. TERRELL \\ University of Hawai ' $i$
}

\section{Introduction}

This paper describes the origins and development of language planning and policy (LPLP) in North Korea. North Korea's idiosyncratic language policies seem to many observers arcane and approaching the fanatical. The country, officially known as the Democratic People's Republic of Korea, is like no other and there are factors unique in the North which must be taken into consideration when attempting or interpret any policy. This is equally true for policies centered on language and its use. In order to truly understand LPLP in North Korea one must keep in mind the distinct social and political situations surrounding LPLPprimarily ideology and propaganda.

Previous studies on language in North Korea have provided some insight on this issue. For example, Kutani (1990) provides an excellent outline for the history of LPLP in the North. Song $(1994,2001)$ addresses the differences in LPLP between the North and the South; pointing out that the North's policies are strictly controlled while the South takes a laissez faire approach. Finally, Lee (1990) offers a good description of dialectal differences between the two states. However, most works either neglect to account for the socio-political setting in the North or do not place enough emphasis on political ideology when interpreting language policies, their uses and results. Therefore, the purpose of this paper is to address this disparity by highlighting the interrelation between political ideology and language policy in North Korea.

For example, in the North, every decision or policy that affects the masses is guided by the theory of Juche, which I will explain in detail in the following section. The policies themselves, whether successful or not, are then reinforced through excessive propaganda and information control. LPLP has an interesting relationship here in that it is directly influenced by Juche, and at the same time plays a role in the reinforcement of the ideology through propaganda. 
Jacob A. Terrell

In order to illustrate this relationship between political ideology and LPLP, section 2 begins by defining Juche. Section 3 is an account of the origins of LPLP in North Korea, with a focus on corpus planning. Finally, section 4 highlights the interrelationship between the two, as they are both guided by and used to reinforce one another.

\section{Defining Juche}

When interpreting any policy from the North, whether it is related to economics, politics or laws dictating one's hairstyle, it is first necessary to address the concept of Juche. The ideology's origins begin with Kim Il-sung, who ruled the country as a stern dictator from 1948 until his death in 1994. It is difficult to provide a concise definition for a notion as far-reaching as Juche. The direct Korean-English translation for Juche is 'self-reliance.' In a simple sense, it is the idea a nation can only become successful if it relies solely on internal resources for all needs of society. In doing so, a nation rids itself of external influences, allowing it to dictate its own path. This is the most basic component of the ideology.

However, there are disturbing underlying themes that accompany this line of thought. The first is that all things foreign in a society are inherently flawed because they originate from a different culture and people, and the mixing of two or more cultures or peoples creates impurity. Additionally, the mere presence of foreign influence or commodities in a society suggests that the nation is inferior due to its need to rely on outsiders. It should be noted that I use the term "foreign influence" loosely. It does not refer to only economic or political influence, but also to the presence of anything foreign: products, culture, religion, vocabulary and so on.

According to Juche, allowing signs of foreign influence to arise suggests that the nation is not self-reliant, while the absence of foreign presence indicates that a nation is strong. These assumptions create a psychological conditioning where there is a need for North Korea to keep all things foreign at bay in order protect the purity of its culture. This also feeds the notion that a true nation is one that is homogeneous, and homogeneity is equivalent to superiority. To illustrate just how serious this idea is taken, below is an abbreviation of a article from the the North's Korean Central News Agency (KNCA), which is North Korea's official English newspaper aimed at an international audience. The quote below from an article titled "Theory of Multiracial Society" is quite lengthy, but it provides a good depiction of North Korea's stance on the importance of a homogeneous society.

A strange farce to hamstring the essential characters of the Korean nation and seek for 'multiracial society' is now being held in South Korea. In this regard Rodong Sinmun 


\title{
Political Ideology and Language Policy in North Korea
}

\begin{abstract}
today runs a signed commentary, which censures the farce as an unpardonable bid to negate the homogeneity of the nation, make South Korea multiracial and Americanize it. ... The South Korean pro-American traitorous forces advocating the theory of 'multiracial society' are riffraffs who have not an iota of national soul, to say nothing of the elementary understanding of the view on the nation and social and historic development.

If the homogeneity of the nation is not kept, the nation and the destiny of individuals cannot be defended. ... The theory of 'multiracial society' is a poison and antireunification logic aimed to emasculate the basic idea in the era of independent reunification. ... This is ascribable to the criminal attempt to make the north and the south different in lineages, block the June 15 era of reunification and seek the permanent division of the nation. (KCNA April 27, 2006)
\end{abstract}

The passage above includes the three main concepts of Juche - the expulsion of foreign influence, homogeneity, and independence through self-reliance. Juche is not only applied to reunification politics. Common themes in North Korean literature include Juche and art, Juche and filmmaking, Juche and the military, the revolution of Juche, agriculture through Juche, Juche as a basis for industry, and so on. It should be no surprise that tenants of Juche can also be found in LPLP.

\section{$3 \quad$ LPLP and Linguistic Prescriptions in North Korea}

The principles for language planning and policy in North Korea were provided by Kim Il-sung in the form of two dialogues. The first dialogue reportedly took place on January 3, 1964. In the talk "Some Problems Related to the Development of the Korean Language," Kim poses questions to a group of unnamed 'linguists' concerning issues facing the Korean language, focusing mainly on vocabulary maintenance. These topics were then revisited in a second dialogue on May 16, 1966 titled: "On Correctly Preserving the National Characteristics of the Korean Language." Each dialogue was later published as "A Talk with the Linguists" in an annual volume of all of Kim's speeches and talks for the respective year, which are interpreted as guidelines and prescriptions for a wide array of issues. Like many of Kim's other publications, there is no evidence that he is the author, or that discussions with linguists concerning language actually took place. Even the date of publication for these talks is under scrutiny (Kutani 1990). Still, whether or not these two particular dialogues took place is beside the point. It is obvious that language and language use was on Kim's agenda. The following sections describe his mandates for status, corpus and acquisition planning, respectively.

\subsection{Status Planning}


Jacob A. Terrell

Status Planning is concerned with increasing the number of domains or functions in which a language is (officially) used. This in turn increases the language's prestige; the more domains a language occupies, the more attractive it is to potential users. Status planning is often an authoritative, top-down affair (though it can also be bottom-up), and in many cases it is used to promote a language in a domain in which elites are able to maintain or expand their power as native speakers (Cooper 1989).

In the North, Korean was already used in all domains of society at the time of these prescriptions. However, the political climate created a need for a new standard dialect to replace the notion that the Seoul dialect was still the standard, as it was before the Korean War and up to these prescriptions (Kumatani 1990). But choosing a Northern dialect as the new standard was not the only problem; in Korean the single term pyojuno means 'standard language.' Thus, the word 'standard language' alone carried indirect reference to the Seoul dialect. Kim was concerned that the ambiguity of using the same term for 'standard language' for two different dialects may cause confusion and mislead people to believe the Seoul dialect is still standard (Kim 1966). In order to avoid this problem Kim coined the term munhwao, or 'cultured language' to be used it in place of pyojuno 'standard language.' Kim declared the Pyongyang dialect the best representation of munhwao 'cultured language' since Pyongyang is the center of the revolution as the nation's capital, and thus munhwao 'cultured language' will be the language of the revolution. This was a very significant move, for it was this decision to differentiate Northern speech from that of the South that began an overhaul of language in North Korea. This initiated a policy of prescription centered on Pyongyang and the revolution of Juche. As the following section shows, this policy marked the beginning of establishing linguistic self-reliance and selfdetermination.

\subsection{Corpus planning}

Once the domains of a language have been increased, there is often a need to expand the lexicon to fulfill the demands of the new domains. Though corpus planning also involves other activities, such as orthography design or revision, corpus planning in Kim's prescriptions focused on coining new terms. Like the case of status planning above, rather than creating new terms to fill any void in the lexicon, Kim stressed the need to create terms to replace those which were already in use. In a rather bold attempt, Kim sought to erase historical traces of foreign influence from the language; in other words, Sino-Korean terms and loanwords were to be eliminated. The following is a list of criteria for replacing foreign and Sino-Korean words with pure Korean counterparts: ${ }^{1}$

\footnotetext{
${ }^{1}$ Adapted from Kim (1966).
} 


\section{Political Ideology and Language Policy in North Korea}

1) If a pure Korean term is synonymous with one of Sino origin, use the Korean term and "cross [the latter] off from the dictionary",

2) use purely Korean names for places (towns, landmarks, etc.) and discontinue the use of their Sino-Korean names,

3) domestic products must be renamed using only pure Korean words,

4) coining of new words will be done strictly in pure Korean,

5) only legitimate words (i.e. pure Korean) can be used to name children,

6) new and existing words for foreign scientific concepts will be translated into pure Korean,

7) military command words should be converted to pure Korean, with stress placed on the final syllable,

8) Chinese characters should not be allowed to appear in school textbooks in any form,

9) a National Language Standardization Commission will be established to oversee this transition.

At the time of these prescriptions, the only dictionary in print in North Korea was the 1962 Choseonmal Sachen 'The Korean Dictionary.' This of course was published before the LPLP prescriptions and it did not conform to the new mandates of munhwao. It was during the first talk with the linguists when Kim, referring to the 1962 dictionary, proclaimed: "this Korean dictionary looks like a Chinese-Korean dictionary (Kim 1964)." Thus, the new policies gave rise to the need for an ideologically fit dictionary. Kim then ordered the compilation of a 10,000 word dictionary free of foreign terms. Amazingly, the first edition of Hyontae Choseonmal Sachen, The Modern Korean Dictionary, was published in 1968. A second edition was released in 1973 titled Choseon Munhwao Sachen, Cultured Korean Dictionary, and a third edition appeared in 1981.

These guidelines for corpus planning represent a drastic attempt to purify the language. Yet, to rid an entire language of loanwords is a quixotic goal at best. As expected, even the most current version of the North's Korean - English dictionary contains loanwords from Russian and English, as well as Sino-Korean terms (Unknown 2002). Still, when compared to a South Korean dictionary the difference in the amount of loanwords and pure Korean words is noticeable (Lee 1990). This in part was accomplished through Acquisition planning and North Korea's peculiar publishing system.

\subsection{Acquisition Planning}

Furthermore, everyone should acquire the spirit of using our language correctly through ideological mobilization and a mass campaign. (Kim Il-sung 1966) 
Jacob A. Terrell

The goal of acquisition planning is a simple one: increase the number of users of a language. In order to do so, users must be provided with an opportunity to learn the language, for example through lessons and materials. At the same time, they must be provided with an incentive to learn, be it self-motivation or compulsory.

As for materials, the mandates above required that all literary work, including textbooks, be rewritten. Future authors too would have to abide by the prescriptions above. This sounds like quite an undertaking, but there is an important concept pertaining to publication in North Korea worth mentioning here. All authors, publishers, and publishing houses are held accountable to the Korean Workers' Party (KWP), which is the organization in charge of propaganda. The main publisher in North Korea, Pyongyang Publishing House answers directly to the KWP; in fact, the Pyongyang Publish House is housed within a smaller branch of the KWP. Should the KWP decide which words are acceptable for print, the publishers have no choice but to agree. It may seem that texts published before these prescriptions would be problematic, but this was not an issue. In order to promote the legitimacy of the new regime, the KWP found it advantageous to destroy or at least rework all literature and publications written before Kim Ilsung's rise to power. Kim himself mentions the need to revise previous literary works in order to make them more compatible with modern times (Kim 1966). That said, the ability of the party to require authors to follow Kim's prescriptions undoubtedly expedited the transition of acquiring the new munhwao 'cultured language' standard.

The motivation to acquire the new munhwao 'cultured language' standard was compulsory, and like most other social campaigns, the one for acquisition planning began with the children. Kim estimated some 5,000 to 6,000 words are necessary for daily use and are common in primary education. He placed an emphasis on training teachers and revising elementary materials first in hopes that children would learn to correct their parents' speech. He also suggests sending copies of the revised elementary textbooks to universities for their use as a standard. Finally, if these prescriptions were not enough to convince the population to switch to the ideologically fit munhwao, Kim recommends "If in the future the people should continue to use any of the words eliminated from the dictionary, we could then rehabilitate them (Kim 1966)."

\section{$4 \quad$ Success of Language Policies in DPRK}

It is an enormous task to convince an entire nation to stop using or replace everyday speech and vocabulary with the new ideologically correct munhwao standard. Yet Kim estimated it could be completed in a few years. Although the politically sensitive munhwao standard requires constant revision, Kim's prescriptions for easing the transition from one dialect to another were quite effective. 


\section{Political Ideology and Language Policy in North Korea}

Although the North has a tendency to boast achieving a one hundred percent rate for anything positive (voter turnout, production rates, etc.), there is reason to believe that the alleged one hundred percent rate for literacy rate holds some truth. Regardless of the quality, education is mandatory in North Korea and all citizens must read and learn to recite literary works of the Kims. Even after education is completed, further study and recitation of Kim Il-sung's work is required in the military, factories, and elsewhere. This is responsible for the high literacy rate in the North. Even the CIA World Factbook (2005) goes as far as to list the literacy rate at ninety-nine percent. Kim's works are all edited to conform to the prescriptions described in the previous sections, and most example sentences in learners' books and dictionaries are quotes from his works. This constant exposure to the new munhwao 'cultured language' likely expedited its dissemination.

In fact, the most striking evidence for the success of these policies is the dialectal differences between North and South Koreans. There was no communication between the two nations from the end of the Korean War until the first ever Pan-Korea summit held in 1972, nearly two decades after the war. During these talks, South Koreans were not shocked by what their Northern brethren had to say, but how they said it (Lee 1990). The language in the North evolved to the extent that there were intelligibility problems. This is the type of evolution that would normally take generations, yet in happened in the North in as little as six years after Kim's prescriptions. The divergence in language continues today. Defectors from North Korea have repeatedly stated in interviews that one of the most difficult things to adjust to in life in the South is the difference in language. They mainly have problems with loanwords, not just those from English or German, but also those from Japanese as well as Sino-Korean words and their usage (Martin 2004).

\section{$5 \quad$ LPLP and Social Control}

Unlike other LPLP case studies, the practice in North Korea has a unique role in society in that the policies are guided by ideology, and then in turn used to reinforce said ideology. This bilateral relationship makes it difficult to determine the boundaries between the ideology, the policies, and propaganda. For example, the establishment of munhwao 'cultured language' based on the Pyongyang dialect and encouraging the population to adapt the new code are typical of how the North Korean government approaches any social issue - they are Pyongyangcentric and implemented through mass campaigns. Moreover, the emphasis on corpus planning is interesting in how it blurs the boundary between language policies and social control; here Juche calls for an ideologically fit language, munhwao, but the language is also used in tandem to support the concept of Juche.

For example, one of Kim's guidelines for vocabulary maintenance is that all North Korean products be renamed in pure Korean. His reasoning for this particu- 
Jacob A. Terrell

lar prescription is interesting. He justifies this decision with the following quote: "[I]f we should leave even these Japanese names as they are how could we explain our prosperity (Kim 1966)." The opposite is just as true. By renaming all foreign products in pure Korean, there is no need to explain the prosperity of other nations, or the regime can attempt to ignore the presentence of foreign goods under the guise of using pure Korean terms for them. (Take, for instance, the terms for 'ice cream' oreum bo sugi and 'computer' cheoncha gesangi in the North, while in the South English-based loanwords are used.)

Some of the best examples of propaganda come from the dictionaries. For example Kumatani (1990) notes a usage tag for entries that refer to notions which conflict with Juche and self-reliance. He states that words for concepts such as kanggan 'rape', appak 'oppression', kangto 'burglar', pinyak 'poverty' and, even chongshinpyong 'incurable disease' are tagged with a usage marker narkun sahoi eso, meaning 'in the old society... .' Most dictionaries contain example sentence illustrating a word's use and context. Unsurprisingly, the example sentences found in The Standard Korean Dictionary are all quotes from Kim Il-sung's speeches (Sae 1994). Finally, the term oangjo 'dynasty' had to be discarded after the son of Kim Il-sung, Kim Jong-il, replaced his father as the leader of the country (Harrold 2004).

The content of the dictionary exemplifies the role of language planning in propaganda and social control. The idea to create a pure Korean dictionary falls under corpus planning. This decision was influenced by Juche, and like the ideology states, the dictionary should not contain foreign words. However deliberately skewing definitions and excluding ideologically unfit terms is using corpus as a tool for social control. This demonstrates how LPLP has an interesting role in North Korea in that its policies are guided by Juche, yet the policies are also then used to reinforce the ideology.

\section{Conclusion}

In linguistics too, Juche should be established so that our language develops systematically and that our people feel national pride and self-respect in speaking and writing it. (Kim 1966)

This is not intended to be an exhaustive list or time line of LPLP in North Korea. However, I hope it is enough to illustrate how the notion of Juche has shaped language planning and policies in the North. The three components to establishing linguistic Juche involve the creation of munhwao 'cultured language' (status planning), overhaul of the lexicon to eliminate foreign influence (corpus planning), and lastly dictating people follow the new policy (acquisition planning). These actions mirror the ideology of Juche in that they seek to promote superiority through homogeneity and self-reliance. This case study is significant in that 


\section{Political Ideology and Language Policy in North Korea}

language policy in North Korea is possibly the best example of a rigorous, topdown policy widely adopted by the speech community. By focusing on an extreme example of how political agenda shapes language policy, it is my hope that this paper will contribute to the growing body of literature of language ideology. 
Jacob A. Terrell

\section{References}

Cooper, Robert L. 1989. Language planning and social change. Cambridge: Cambridge University Press.

CIA. 2005. The world factbook. Washington, DC: CIA. Available online: www.cia.gov/cia/publications/factbook

Harrold, Michael. 2004. Comrades and Strangers. West Sussex, UK. Wiley \& Sons Ltd.

Kumatani, Akiyasu. 1990. Language Policies in North Korea. International Journal of the Sociology of Language 82. 87-108.

Kim Il-sung. 1964. Some problems related to the development of the Korean language. ed. unknown, in On juche in our revolution. 384-397. Pyongyang, N. Korea: Foreign Languages Publishing House.

Kim Il-sung. 1966. On correctly preserving the national characteristics of the Korean language. ed. unknown, in On juche in our revolution. 511-528. Pyongyang, N. Korea: Foreign Languages Publishing House.

Korean Central News Agency. 2006. Rodong sinmun censures theory of multiracial society, April 27, 2006. Available online: www.kcna.co.jp/

Lee, Hyun-Bok. 1990. Differences in language use between North and South Korea. International Journal of the Sociology of Language 82: 71-85.

Martin, Bradley K. 2004. Under the Loving Care of the Fatherly Leader. New York: St. Martin's Press.

Song, Jae Jung. 1994. Language Policies in North and South Korea. Language Quarterly 32: 205-212.

Song, Jae Jung. 2001. North and South Korea: language policies of divergence and convergence. Language and language policy: East Asian Perspectives, ed. by Nanette Gottlieb and Ping Chen, 129-157. Richmond, UK: Curzon Press.

Author Unknown. 2002. Big Korean - English Dictionary. Pyongyang, North Korea: Pyongyang Publishing House.

Department of Linguistics

College of Languages, Linguistics, and Literature

University of Hawai'i at Mānoa

1890 East-West Road

Moore Hall 569

Honolulu, HI 96822

jterrell@hawaii.edu 